\title{
MICROCREDIT FINANCIAL INSTITUTIONS IN THE FUNCTION OF ENTREPRENEURSHIP DEVELOPMENT
}

\author{
Dušan Aničić, ${ }^{1}$ Nataša Simić, ${ }^{2}$ Vesna Petrović, ${ }^{3}$ \\ ${ }^{1}$ DSN Consalting, Zaplanjska 86 v, 11000 Belgrade \\ ${ }^{2,3}$ Faculty of entreneurship and real estate management, Union University-Nikola Tesla, Belgrade \\ anicic.dusan@yahoo.com,nsimic68@gmail.com, al.petrovicpn@gmail.com
}

\section{Professional Paper doi:10.5937/jouproman6-16902}

\begin{abstract}
High unemployment rate, low competitiveness level, high level of foreign debt and low GDP per capita are all basic indicators of (un)developed economy in Serbia, present throughout the period of transition. Since large economic systems, especially in industry and agriculture, have been completely devastated in the transitional period, entrepreneurship model is imposed as the most efficient type of economic development and connection to the developed countries. One of the greatest obstacles to successful entrepreneurship development in Serbia is funding conditions dominated by the banking sector, and the rest of the funding types appropriate for the entrepreneurs' true needs are largely neglected. The creation of adequate legislation for microcredit institution development that would primarily finance entrepreneurship and family business development would have a significant positive effect on the development of this sector.
\end{abstract}

Keywords: entrepreneurship, financing, microcredit institutions

\section{Introduction}

Entrepreneurship represents one of the directions for sustainable economic development of the countries in the period of transition because it has already had positive results in the economically developed countries. In order to achieve that, a favourable macroeconomic environment for family business and entrepreneurship development should be created in the complete territory of the Republic of Serbia. In addition to government institutions, entrepreneur associations, the Association of Small and Medium Enterprises and Entrepreneurs, state and private universities, as well as other educational institutions, international and local organisations and associations must have an important role in the creation of the favourable environment for entrepreneurship development.

Positive effects of entrepreneurship development are unemployment reduction, unfavourable migration prevention, work productivity increase and the adoption of innovative solutions in economy. Among the greatest obstacles in entrepreneurship development are unfavourable funding conditions for entrepreneurial ventures. Banking sector is dominant among the funding resources, with high interest rates and inadequate loan terms, unadjusted to entrepreneurs' true needs and requirements. Adequate legislation for the development of microcredit institutions and other types of funding is expected from the competent state institutions, adjusting their business to entrepreneurship and family business development requirements.

\section{The problems of entrepreneurship development from the aspect of financing}

In Serbia, entrepreneurship has not reached the necessary level of development, nor the one proclaimed by the economic policy after the year 2000 . Therefore, all negative results of the transitional processes are still present, from high level of unemployment and low competitiveness to the high level of foreign debt. 
Entrepreneurship could be the key factor in achieving desirable changes in Serbia, such as: work productivity increase, product and service quality increase, competitiveness strengthening, better usage of available capacities, increased exports, higher employment, public and foreign debt reduction, etc.

Considering the high rate of foreign debt, GDP structure (where almost two thirds are generated by the non-tradable sectors), high foreign trade deficit as well as negative consequences of the environment from the previous years, it is clear that the economic policy creators in Serbia are faced with a difficult task of how to stop the negative trends in economy, and thus in the area of entrepreneurship development and unemployment reduction. These circumstances impose the issue of the change in the economic policy which will lead to sustainable growth and development in the economy, eliminate regional disparities, provide the necessary level of investments, as well as favourable environment for SMEs sector development. The affirmation of entrepreneurship in general, and particularly manufacturing entrepreneurship, can be a good start for progressive and undoubtedly pragmatic transformation and transition of our society towards economically developed countries.

Entrepreneurship and self-employment in Serbia represent the areas that gained in significance with the changes in the context of economy - privatisation, the change in economic and ownership structure, the increase in possibilities of losing a job and workforce market instability. The changes in the economic structure also cause a completely new approach to human resources (demand for new knowledge, skills and high competencies, mobility, adaptability, etc). Entrepreneurial education has both shortterm and long-term effects in the society and higher education significantly increases the prospects of entering entrepreneurship for business chances and ideas rather than out of economic necessity (Grbovic et al, 2013).

One of the directions of sustainable economic development is entrepreneurship that had positive results in the economically developed countries. However, business environment for entrepreneurship development in Serbia is still unfavourable, with almost all the obstacles from the beginning of the transitional period, despite declarative support of economic policy creators. Solving the problem of unemployment, preventing the migration of young professionals, increasing work productivity and innovation adoption are just some of the positive effects of entrepreneurship development. In addition to state institutions, entrepreneurship associations, the Association of Small and Medium Enterprises and Entrepreneurs, as well as state and private universities, international and local organisations and associations must play an important role in the process of creating a favourable environment for entrepreneurship development.

During the whole period of transition the conditions for financing were very unfavourable, the forms and scope of financial support inadequate: banks with expensive credit offer and short terms of repayment dominate, and there is a lack of more developed credit institutions at the national and regional level, as well as other instruments of financing suitable for SMEEs real financial needs and their economic strength. Also, there is still undeveloped programme approach to finances - cooperation with private investors, credit and credit guarantee programmes, loans without collateral for providing capital for innovative SMEEs, risk capital funds capitalisation, tax incentives, etc. 
The indicators of business in economy in the previous years show that the basic rules of financing have been violated in our economy, both vertical (the relation of own capital to borrowed capital, the relation of long-term and short-term sources) as well as horizontal (financial balance and stability), which is reflected to the negative cash flow in SMEEs, that is, long-term insolvency. In such a situation, the level of company's financial stability is low, as well as the level of financial and total business independence and autonomy in business decision making.

According to the above mentioned, all new ideas about the SMEEs sector way of financing which lead to cost reduction are extremely important for the developmentoriented economy. One of the models is company financing according to the Regulation on incentives for entrepreneurship, with the general goals of investment support, business expansion and local business subjects' integration into supplier chains for large systems.

The specific goals of the programme are support for investment in building large production capacities, increasing production and turnover value and scope, competition strengthening and employment support.

The significance of state support for entrepreneurship development through various programmes is reflected in the efficiency increase of the complete economy. The development of entrepreneurial spirit animates the competition to encourage business internationalisation, export increase and the need for new workers, directly influencing the reduction of unemployment rate and increase in the standard of living. Government aid often means easier fund obtaining for entrepreneurs and contracting of special types of business that financial institutions often do not recognize. The aid of government can be direct or through subjects authorised by the government. The types of government aid include grants, donations, guarantees, loans with favourable conditions, etc.

There are clear principles and rules in case of financial support for entrepreneurs and micro companies in the EU countries, such as the principle of cost necessity and justification which should be accurately defined and pre-determined. Furthermore, government aid must have a wider influence (multiplicity effect) on new job openings, competitiveness increase and export orientation. Aid beneficiaries have an obligation to report to funders regularly, and they have to repay the funds with the corresponding default interest in case of mismanagement.

Incentives for entrepreneurship development and SMEs in Serbia have become common after the year 2000 when support programmes gained important role considering the ongoing market conditions where private business had small chance of survival. Insufficiently developed banking sector, great distrust in financial institutions, large share of grey economy, large company monopoly, undeveloped awareness and regulations for private business development demanded direct and intensive financial and non-financial aid on behalf of the state for entrepreneurship activity development.

It is expected from the government to diminish the negative impact of external factors on the businesses in Serbia (Jankovic, et all, 2016). In the era of constant changes in all the spheres of business, important factors of the survival of the enterprise are keeping track of the events in the region, swift reactions to actual trends and predicting the future market events. By this means the enterprises become more successful and achieve a proactive control over their future (Gavrić, et all, 2016). 
At present, the efforts of the state to create necessary monetary, credit and fiscal policy in order to relieve the budget and enable external financing sources acquisition under favourable conditions. The creation of incentive environment by the state implies definition and implementation of necessary regulations, supportive measures and tax system improvement as well as the activities of the appropriate institutions for entrepreneurship and SMEEs development support. The institutional framework in the area of financial support for SMEs and entrepreneurship after the year 2000 consists of the Ministry of Economy and Regional Development, the Fund for Development of the Republic of Serbia, the Fund for Development of the Autonomous Province of Vojvodina, the Guarantee Fund of the Republic of Sserbia, Serbian Export Credit and Insurance Agency, National Employment Service, Development Agency of Serbia, etc.

\section{Microcredits as an opportunity to improve entrepreneurship and SMEs financing}

SMEEs sector has an opportunity to provide the necessary funds for investment project implementation in one of the following ways:
1. self-financing,
2. lending,
3. joint investments,
4. issuing and sale of securities,
5. leasing,
6. concessive financing, etc.

The experiences in microcredit programme implementation in different countries speak in favour of rising demand for this source of finance. The reasons should be found in the fact that loans intended for micro and small enterprises are very risky for banks, because these enterprises are faced with a number of challenges, such as dynamic and continuous changes in the market, high level of failure, the absence of proper legislation, unfavourable business environment, difficulties in collateral provision, etc.

The absence of the appropriate legislation has an insufficient development of microcredit financing as a consequence. There are just a few microcredit organisations registered as civic associations or non-government organisations in Serbia, performing their credit activities through banks, offering available funds on commission. The banks make a loan payment, while microcredit organisations perform all other tasks related to finding the clients, loan application techical processing, intended loan utilisation control, etc. Due to the limitations caused by the currently valid regulations, microcredit organisations perform a large share of business in the loan approvement procedure, while the banks only appear formally as creditors.

The most common obstacles to bank credit usage are the lack of appropriate collaterals, non-existent paperwork on business ventures and enterprise, impossibility of presenting the project to the potential creditors in an adequate way,the unadjusted methodology for small project evaluation which makes the success evaluation process too expensive (Paunovic, Novkovic, 2003). The necessary cash assets are not obtained very fast so there is a negative cash flow as a result, and the positive cash flow is the most important in the starting phases of the development, the profitability will come later (Lucic, 2006).

Business banks rarely approve microcredits in order to satisfy the needs of the families with low income. Limited access to loans for starting an entrepreneurial business of the above mentioned population category is connected to the practical difficulties the banks face. On the one hand, the banks demand that the debtors have stable income sources to repay the principal and interest according to repayment terms. 
However, the income of self-employed entrepreneurs or small enterprises is often irregular and uncertain, so they are mostly considered as high-risk clients for the banks. Besides, the approval of a large number of small loans significantly increases bank expenses, so the banks rather approve larger loan amounts to fewer clients and therefore minimise their costs. When it comes to loan insurance, banks demand guarantees and collaterals with clear ownership which many micro enterprises and beginner entrepreneurs in business lack. The reasons banks are generally not interested in micro-crediting in the market led to the appearance of organisations that credit low-income families, beginner entrepreneurs and micro enterprises.

Microcredit institutions have consultants helping each client understand loan terms and conditions, fill in the appropriate forms, write a business plan and prepare the necessary documents. In the procedure of document provision the client have to supply specific information concerning income, expenditure, prices, suppliers, market, buyers, products and other elements crucial for economic and financial analysis. This is the way to create a realistic picture about economic feasibility of the investment and the possibility for its regular servicing by the client. After the loan disbursment and the beginning of its use, the microcredit organisation monitors and controls the specific purpose loan utilisation.

SMEs and entrepreneur sector business analysis indicates a number of specific points, and the basic one is that this sector is faced with great problems in its basic business model, with financing issues often having the most important role. This sector is forced to solve its problems by reducing costs as a result of supply level reduction, labour cost reduction through earning reduction or employee dismissal. Another way is by obtaining alternative sources of working capital, primarily by the extension of liability payment deadline to suppliers. All the above mentioned leads to planned investments deferment or termination.

SMEs and entrepreneur sector often have fewer opportunities to change over to another economic activity in relation to financially stronger, larger enterprises. The result is weaker financial performance, focus on local micro markets and dominanat role of non-productive industries. Recognising these problems, the appropriate EU institutions started a number of programmes with the aim of facilitating this segment of economy to gain easier access to funds. That is why large banks, such as the European Bank for Reconstruction and Development (EBRD), KfW Development Bank from Germany, the European Investment Bank (EIB), created joint funds to facilitate SMEEs project financing that commercial banks have no interest or finacial resources for.

The most important programmes in this segment are (Marinkovic, 2012 ${ }^{1}$ ):

1. covering the risk share banks face through issuing guarantees for loans approved to SMEEs sector;

2. promotion of using EU structure funds for business growth in SMEEs sector financing;

3. financing of credit lines for fund placement with mediation of business banks operating in local banking markets.

Credit line model is the most represented one in the financial market of Serbia.

\footnotetext{
${ }^{1}$ Marinković, M., (2012) SMEs sector financing: reality and possibilities, Macroeconomic analyses and trends, Belgrade pp 39-41
} 
Business banks have the access to the above mentioned investors resources, whether directly or through the National Bank of Serbia, and they facilitate longterm financing for their clients, with better loan terms and conditions.

The particular fact about SMEEs sector in Serbia is often the lack of good-quality projects so a better share of the loan potential remains unused. Some of the international institutions programmes in Serbia are known as: Investments in fixed assets, Investments in permanent working assets, Investments in energy efficiency improvement, Development investment projects and working assets, Entrepreneurship development, etc.

In the Republic of Serbia, SMEEs sector can provide funds from various resources in the market, such as: commercial bank loans, leasing companies, factoring, angel investors, microcredit organisations, capital market - shares, bonds, etc. If its companies are funded properly, SMEEs sector contributes the economic development by creating new jobs, labour market diversification, long-term change facilitation in employment patterns such as workforce crossover from public to private sector. In ordrer to provide a better, sustainable access to funds, it is necessary to remove obstacles in the market which prevent private capital flow towards SMEEs sector.

There is negative influence of several factors in SMEEs sector financing conditions, such as worse conditions for doing business in macroeconomic environment and less risk preference. All these things influence a number of subjects in this sector to abandon formal economy and enter the grey area of economy. This undermines the competitiveness of the companies which do business according to the regulations and regularly pay the corresponding taxes and contributions. Entreprenership financing is also influenced by a number of factors related to the attitude and behaviour of entrepreneurs and SMEs. Market feedback indicates that the borrower's aversion to risk-taking, false perceptions, inadequate knowledge and poor borrowing culture all contribute to the problems in financial resources access and lead to the negative attitudes. Loan terms and conditions demanding personal guarantees and distinctively high collateral level additionally deteriorate aversion to risktaking. Having too high expectations from government support can influence the choice of the moment for financial decision making and distort the user's feeling of fair market conditions for lending.

Regarding the aim of eliminating the shortcomings in the market which lead to financial neglect of entrepreneurs and SMEs sector, the measures to be taken are non-banking sector and alternative forms of financing promotion with proper control of the competent authorities. Also, it is necessary to establish a unique legislative framework for non-banking, non-deposit credit institutions and improve the existing regulations related to factoring, considering long terms of repayment in this sector. The improvement of regulations in leasing could lead to opportunities for machine and equipment financing in industry and agriculture under flexible conditions and without mortgages. The governmet is expected to provide a set of measures in order to stimulate the business banks to lend to entrepreneurs and SMEs. Furthermore, regional and local financial institutions should be encouraged to work towards bringing their services closer to the potential clients. 


\section{Conclusion}

Entrepreneurship has an important role in the economic development of every country, and it is reflected in productivity and competitiveness level increase, product quality improvement, innovation adoption, employment and export increase, public debt reduction, etc. Entrepreneurship development in Serbia should be supported by the government, as well as the other participants in the economic development process; this is for the reasons of completely devastated economic structure after the year 2000, especially large industrial and agricultural companies.

It is beyond doubt that the existing models of entrepreneurship financing, which are based on the banking sector domination, will not significantly contribute to its fast and sustainable development. Therefore, regulatory institutions in the Republic of Serbia should create the legal assumptions for the development of microcredit institutions with the main task of monitoring entrepreneurship and family business development. In this respect, financial institutions providing funds for entrepreneurship development at the regional and local level would be very important. That could provide multiple positive effects through employment increase, more balanced regional development and conditions for the young to remain in local environment.

\section{References}

Gavrić, G., Kirin, S., Karavidić, C, M., (2016)

Adaptability of companies in the Republic of Serbia - emirial research; Ekonomika, Vol. 62, No 4, p 115-128.

Grbović, D., Zakić, N. \& Vukotić, S. (2013). Women education in the function of female enterpreneurship development in Serbia, 4th Women and Business Conference, Bulgaria

Janković, M., Mihajlović, M., Cvetković, T., (2016) Influence of external factors on business of companies in Serbia, Ekonomika, Vol. 62, No 4, p 31-38.

Lučić, LJ., (2006) Preduzetničke finansije, Akademska misao, Novi Sad, s. 58-59.

Marinković, M., (2012) Finansiranje sektora MSP : realnost i mogućnosti, Makroekonomske analize i trendovi, Beograd, str. 39-41

Paunović, B., Novković, N., (2003) Mogućnosti i uslovi finansiranja malih i srednjih preduzeća, Časopis za procesnu tehniku i energetiku $u$ poljoprivredi, /PTEP, vol.7, br 1-2 